\title{
The Effect of Warm Compress on Low Back Pain during Pregnancy
}

\author{
Shinta Novelia ${ }^{*}$, Rukmaini Rukmaini², Siti Anisah ${ }^{3}$
}

1,2,3Department of Midwifery, Universitas Nasional, Indonesia; shinta.novelia@civitas.unas.ac.id (Corresponding Author)

\begin{tabular}{ll}
\hline Article Info: & ABSTRACT \\
\cline { 2 - 2 } $\begin{array}{l}\text { Submitted: } \\
\text { 19-08-2021 }\end{array}$ & $\begin{array}{l}\text { Back pain is one of the discomforts experienced by pregnant women in the third } \\
\text { trimester. From some of the discomforts of pregnant women in Kilasah Village, } 32\end{array}$ \\
Revised: & samples of TM III pregnant women who experienced back pain were taken. This study \\
30-08-2021 & aims to observe the intensity of back pain before and after being given warm \\
Accepted: & compresses. This study aimed to determine the effect of warm compresses on lower \\
15-11-2021 & back pain among third trimester pregnant women who do pregnant exercise in Kilasah \\
& $\begin{array}{l}\text { Village, Kilasah Health Center Work Area, Kasemen District, Serang City. This study } \\
\text { used a quasi-experimental research design with a control group design. The sample in }\end{array}$ \\
DOI: & this study was pregnant women of third trimester in the village of Kilasah. The samples \\
https://doi.org/10.53713/nhs.v1i3.55 & was 32 respondents who were divided into two groups; 16 intervention groups and 16 \\
& control groups. The results of this study indicate that there was a difference in the level \\
& of low back between the intervention group and the control group (p value $=0.000)$. It \\
is hoped that the results of this study can become the basis for developing methods to \\
reduce low back pain in third trimester pregnant women.
\end{tabular}

This work is licensed under CC BY-SA License.

Keywords: pregnancy; low back pain; warm compress

\section{INTRODUCTION}

The prevalence of spinal pain in pregnant women was more than $50 \%$ in the United States, Canada, Iceland, Turkey, Korea, and Israel. Meanwhile, in non-Scandinavian countries such as northern America, Africa, the Middle East, Norway, Hong Kong and Nigeria, the prevalence is higher, ranging from $21 \%$ to $89.9 \%$ (Hakiki, 2015). The results of research on pregnant women in various regions in Indonesia reach $60-80 \%$ of pregnant women experiencing back pain (Mafikasari et al., 2015). According to research conducted by Lichayati and Kartikasari (2013), the results showed 75\% pregnant women who had never done pregnancy exercise have back pain. Low back pain during pregnancy occurs because of Changes in pregnancy hormones that increase relaxant hormones (hormones that make muscles relax and weak), this affects the flexibility of ligament tissue which ultimately increases joint mobility in the pelvis and will have an impact on spinal and pelvic instability and cause back pain.

Predisposing factors for pelvic pain include uterine growth that causes changes in posture, weight gain, the effect of the hormone relaxin on ligaments, previous history of pelvic pain, parity and activity (Casagrande, Gugala, Clark, \& Lindsey, 2015).). The growth of the uterus that is in line with the development of pregnancy results in the stretching of the supporting ligaments which is usually felt by the mother as a very painful stabbing spasm also called ligament pain, this is what causes lower back/pelvic pain. In line with the gradual increase in weight during pregnancy changes body posture so that the center of gravity of the body shifts forward. There is a tendency for the back muscles to shorten when the abdominal muscles are stretched, which can cause muscle imbalance around the pelvis and additional tension can be felt over the ligaments.

One way to reduce low back pain during pregnancy is by doing pregnancy exercises. Pregnancy exercise is a therapeutic motion exercise to prepare pregnant women, physically or mentally, for a fast, safe and spontaneous delivery. Pregnant women are encouraged to take part in pregnancy exercise when the womb has reached the age of 6 months (Asrinah, 2010). According to Agnesia (2010), the most suitable type of exercise for pregnant women is pregnancy exercise, adjusted to the number of physical changes such as the genital organs, the abdomen is getting bigger, and so on. Pregnant women prepare everything that can help during pregnancy and during the delivery process, one of which is by doing pregnancy exercises. Following pregnancy exercise regularly can maintain optimal health of the body and fetus (Widianti \& Proverawati, 2010). This pregnancy exercise can relieve complaints of pelvic pain felt by pregnant women because in pregnancy exercise there are movements that can strengthen the abdominal muscles (Megasari, 2015). Following pregnancy exercise regularly can also maintain a healthy body and can relieve low back 
pain felt by pregnant women. In addition to pregnancy exercise to reduce lower back pain, which was with warm compresses.

The effectiveness of warm compresses is to reduce the back pain scale because giving warm compresses can have the effect of increasing muscle relaxation, increasing circulation and increasing comfort together which is achieved through skin stimulation. Puspitasari (2013) found that there was a relationship between pregnant women who do pregnancy exercises with back pain. The more regularly you take part in pregnancy exercises, this can minimize the back pain felt by pregnant women. Based on the preliminary study and interviews, the coordinator of the Kilasah Health Center said that the Kilasah Health Center had a class program for pregnant women which was routinely carried out every $4 \mathrm{x}$ month with counseling activities and pregnancy exercises. From the results of the initial survey out of 34 trimester III pregnant women, majority of them (80\%) experience lower backpain and don't know about warm water intervention. Thus, this study aimed to determine the effect of warm compressn on low back pain of TM III pregnant women at the work area of Kilasah Health Centre Serang City in 2019.

\section{METHOD}

This type of research is a quasy experiment. This research was conducted at the Kilasah Health Center, Serang City, Banten which was held in July 2019. The population was third trimester pregnant women who took a pregnancy exercise class at Kilasah Health Center at the time of the study. A purposive sampling technique was used. The study was conducted from July 10 to July 26, 2019. A total of 32 pregnant women were joined this study and divided into two group experiment and control. A numeric rating scale was used to measure low back pain among pregnant women. The exclusion criteria were women with pregnancy complications.

\section{RESULT}

Table 1. The pain level in the experiment group

\begin{tabular}{lcccc}
\hline \multirow{2}{*}{ Back pain } & \multicolumn{2}{c}{ Pretest } & \multicolumn{3}{c}{ Post test } \\
\cline { 2 - 5 } & $\mathrm{f}$ & $(\%)$ & $\mathrm{f}$ & $(\%)$ \\
\hline Low & 14 & 87.5 & 14 & 87.5 \\
\hline Mild & 0 & 0 & 0 & 0 \\
\hline Severe & 2 & 12.5 & 2 & 12.5 \\
\hline Total & 16 & 100 & 16 & 100 \\
\hline
\end{tabular}

Table 1 shows that majority of respondent of experiment group experienced low level of pain (87.5\%) in both measurement pre and post test.

Table 2. The pain level in the control group

\begin{tabular}{lccccc}
\hline \multirow{2}{*}{ Back pain } & \multicolumn{3}{c}{ Pretest } & \multicolumn{2}{c}{ Post test } \\
\cline { 2 - 5 } & $\mathrm{f}$ & $(\%)$ & $\mathrm{f}$ & $(\%)$ \\
\hline Low & 0 & 0 & 0 & 0 \\
\hline Mild & 16 & 100 & 16 & 100 \\
\hline Severe & 0 & 0 & 0 & 0 \\
\hline Total & 16 & 100 & 16 & 100 \\
\hline
\end{tabular}

Table 2 shows that all respondents of control group experienced mild level of pain (100\%) in both measurement pre and post test.

Table 3. The differences of back pain between experiment and control group

\begin{tabular}{lcc}
\hline Low back pain & Mean & $p$ \\
\hline Experiment group & 2.38 & 0.000 \\
\hline Control group & 5.38 & \\
\hline
\end{tabular}


Table 3 shows that the mean of pain in the control group was 2.38, while the pain in the experiment group was 2.38. The bivariate analysis found $p$ value was .00 which mean that there was a significant difference of pain between experiment and control grup.

\section{DISCUSSION}

This is in accordance with the results of research conducted by (Rahmawati, et al 2012) found that respondents who experienced back pain before intervention, it can be seen mostly in the range of mild pain category that was $54.5 \%$ and moderate pain category that was $45.5 \%$. Pain is a production mechanism of the body, arises when the tissue is damaged, and causes the individual to react to relieve pain (Prasetyo, 2010).

The results related to research of Hidayat (2008) which found many complaints and discomforts felt by pregnant women. One of the discomforts in the third trimester of pregnancy is low back pain. In general, back pain in pregnant women is influenced by several factors: changes in body posture, this is in line with gradual weight gain during pregnancy and redistribution of ligaments, the body's center of gravity shifts forward and when combined with weak abdominal muscle stretches, this often occurs. This results in indentation of the shoulders, there is a tendency for the back muscles to shorten if the abdominal muscles are stretched, which can cause muscle imbalance around the pelvis, and tension can be felt over the ligaments (Uliyah \& Hidayat, 2018). This condition is exacerbated by the growth of the fetus in the womb which puts pressure on the internal organs, bones and nerves, thereby increasing the pain experienced by pregnant women in the last months of pregnancy. Besides that, what makes back pain increase is when the fetus moves in the womb. So, the longer or increasing gestational age, the more the weight of the fetus increases, the more frequent back pain will occur (Bobak, 2014).

Warm compresses are to provide a feeling of warmth to meet the need for comfort, reduce or relieve pain, reduce or prevent muscle spasms and provide a feeling of warmth in certain areas (Uliyah \& Hidayat, 2008). The use of warm compresses on areas of tension and pain is thought to relieve pain by reducing muscle spasm caused by ischemia, which stimulates pain and causes vasodilation and increased blood flow to the area (Walsh, 2008). The results showed that the second measurement (posttest) in the control group obtained an average pain of 5.38 with a standard deviation of 1.088 , while the second measurement (posttest) in the intervention group obtained an average pain of 2.38 with a standard deviation of 0.885 . From these results, it can be seen that there is a difference or difference in the average pain in the second measurement (posttest) between the control group and the intervention group of 3,000 .

The results of statistical tests obtained $p$ value 0.000 , at alpha 0.05 obtained $p<a$, it can be concluded that there is a difference in the decrease in low back pain levels between the intervention group and the control group, where in the intervention group or the group receiving warm compresses the decrease is greater pain scale compared to the control group or those who did not receive warm compresses. These results related to the theory of Potter \& Perry (2011) which states that warm water compresses are one of the cutaneous stimulations carried out to relieve pain with a working principle that is in accordance with the gate-control theory. Pain impulses can be regulated or inhibited by defense mechanisms along the nervous system center. This theory suggests that pain impulses are transmitted when a barrier is opened and impulses are inhibited when a barrier is closed.

The results of this study are also in line with the study of Alloya (2016) which found that warm compresses were effective in reducing low back pain in third trimester pregnant women with an average of 7.2 to 3.6 after giving warm compresses. Likewise, the Saudia \& Sari research (2018) which found that warm compresses could reduce back pain in third trimester pregnant women by 0.733 . Mayani \& Suyani's (2018) research on the effect of pain intensity before and after giving warm compresses to third trimester pregnant women at the Pelita Hati Banguntapan Clinic, Bantul Yogyakarta concluded that there was an effect of pain intensity before and after giving warm compress with a $p$ value of 0.000. Researchers argue that the decrease in the low back pain scale for pregnant women in the third trimester after receiving a warm compress intervention is not only caused by the physiological factors described above, but can also be influenced by psychological factors. Pregnant women who get this warm compress therapy will feel calm, comfortable, relaxed, and will be closer to the health workers who serve, because both can be done simultaneously so that indirectly this can reduce the level of pain felt. This intervention is needed to be shared to pregnant women in order to reduce back pain during pregnancy. 


\section{CONCLUSION}

There was a significant difference in the level of low back pain between the intervention group and the control group, where the intervention group or the group that received warm compresses had a greater reduction in pain scale than the control group or those who did not receive warm compresses. Warm compress is effective to reduce low back pain among trimester III pregnant women. Midwife need to practice warm compress to improve the comfortness of pregnant women during their pregnancy. Furthermore, the pregnant women family need to know how to practice warm compress to help pregnant women overcome their low back pain.

\section{ACKNOWLEDGEMENT}

The authors thank to Universitas Nasional which provided partial funding for the research.

\section{REFERENCES}

Alloya, A. (2016). Beda Pengaruh Antara Senam Hamil Dengan Kompres Hangat Dan Massage Terhadap Penurunan Nyeri Punggung Bawah Pada Ibu Hamil Trimester III. Publikasi Ilmiah. Surakarta: Universitas Muhammadiyah Surakarta.

Asrinah, P. S., Sulistyorini, D., Muflihah, I., \& Sari, N. D. (2010). Asuhan Kebidanan Masa Persalinan. Yogyakarta: Graha IImu. Bobak, (2014). Keperawatan Maternitas. Jakarta, EGC

Casagrande, D., Gugala, Z., Clark, S. M., \& Lindsey, R. W. (2015). Low back pain and pelvic girdle pain in pregnancy. JAAOSJournal of the American Academy of Orthopaedic Surgeons, 23(9), 539-549.

Hidayat. (2008). Pengantar IImu Kesehatan Anak untuk Pendidikan Bidan. Jakarta: EGC.

Hakiki, I. (2015). Efektifitas Terapi Air Hangat Terhadap Nyeri Tulang Belakang Pada Ibu Hamil Di Wilayah Kerja Puskesmas Pisangan Mahasiswa PSIK UIN Syarif Hidayatullah Jakarta.

Lichayati, I. U., \& Kartikasari, R. I. (2013). Hubungan senam hamil dengan nyeri punggung pada ibu hamil di Polindes Desa Tlanak Kecamatan Kedungpring Kabupaten Lamongan. Jurnal Surya, 1(16), 63-70.

Mafikasari, A., \& Kartikasari, R. A. (2015). Posisi tidur dengan kejadian back pain (nyeri punggung) pada ibu hamil trimester III. Surya, 7(02), 26-34.

Maryuani, A. 2010. Nyeri Dalam Persalinan. Jakarta: Trans Info Media

Megasari, M. (2015). Hubungan senam hamil dengan nyeri punggung pada ibu hamil trimester III. Jurnal kesehatan komunitas, 3(1), $17-20$.

Perry \& Potter, 2012. Buku Ajar Keperawatan Medika Bedah. Edisi 8 volume 2. Jakarta: EGC.

Prasetyo, 2010. Konsep dan Proses Keperawatan Nyeri. Yogyakarta: Nuha Medika

Rahmawati, N. A., Ma'arij, R., Yulianti, A., Rahim, A. F., \& Marufa, S. A. (2021). Prenatal Yoga Efektif Mengurangi Nyeri Punggung Bawah pada Ibu Hamil. Physiotherapy Health Science (PhysioHS), 3(1), 18-21.

Saudia dan Sari (2018). Perbedaan Efektivitas Endorphin Massage dengan Kompres Hangat Terhadap Penurunan Nyeri Punggung Ibu Hamil Trimester III Di Puskesmas Wilayah Kerja Sekota Mataram. Jurnal Kesehatan Prima.

Uliyah, M \& Hidayat, A. (2008). Ketrampilan Dasar Praktik Klinik. Jakarta: Salemba Medika.

Ummah, Faizzatul. (2012). Nyeri Punggung Pada Ibu Hamil Ditinjau Dari Body Mekanik

Widianti, A. T., \& Proverawati, A. (2010). Senam kesehatan. Yogyakarta: Nuha Medika. 